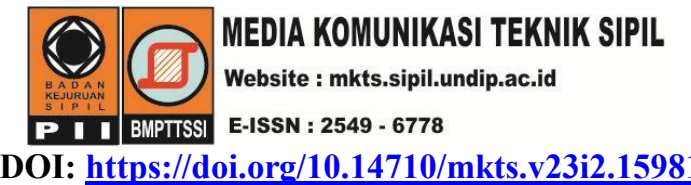

\title{
Analisis Banjir dan Perencanaan Desain Transportasi Sungai di Kota Bojonegoro
}

\author{
"Rian Mantasa Salve Prastica, Caya Maitri, Pratomo Cahyo Nugroho, Ade Hermawan \\ Program Studi Teknik Sipil, Universitas Indonesia \\ *) rian.mantasa@ui.ac.id, rianmantasasp@gmail.com
}

Received: 15 September 2017 Revised: 31 Oktober 2017 Accepted: 10 November 2017

\begin{abstract}
One of the worst problem in Bojonegoro is flood. This research aims to know the factor that could become the factor of flood in Bojonegoro. Besides that, this research analyses the planning of transportation river design in Bojonegoro. Flood discharge analysis uses Nakayasu synthesis unit hydrograph for period of 5 years, 10 years, 25 years, 50 years, and 100 years, then they would be compared to the water maximum capacity that could be loaded by the river. According to the analysis result, Bengawan Solo River in Bojonegoro could not able to load flood discharge from Nakayasu synthesis unit hydrograph analysis for all periods. The result conclusion that captured by HEC-RAS application has the same idea. It shows flood water surface is more than full bank capacity elevation. For river transportation design planning, according to analysis of parameter of depth, width for one and two lanes, turning basin and its depth, the ship design that recommended to ship in the Bengawan Solo River in Bojonegoro are cargo ship and passenger ship with draft of $0.6 \mathrm{~m}$ and LOA of $18 \mathrm{~m}$, or the capacity of a passenger ship is 70 people.
\end{abstract}

Keywords: Flood, Nakayasu synthesis unit hydrograph, HEC-RAS, river transportation

\begin{abstract}
Abstrak
Salah satu permasalahan Kota Bojonegoro adalah banjir. Penelitian ini bertujuan untuk mengetahui penyebab banjir yang terjadi di Bojonegoro. Selain itu, penelitian ini mengkaji analisis perencanaan desain transportasi sungai di Bojonegoro. Karena belum ada sarana transportasi di Bojonegoro, penelitian ini bertujuan menganalisis hal tersebut. Debit banjir rencana HSS Nakayasu dengan kala ulang 5 tahun, 10 tahun, 25 tahun, 50 tahun, dan 100 tahun dan dibandingkan dengan kapasitas maksimum air yang bisa ditampung oleh sungai. Berdasarkan hasil analisis tersebut, Sungai Bengawan Solo di Bojonegoro tidak mampu menampung debit banjir rencana semua kala ulang. Kesimpulan hasil yang sama ditampilkan oleh aplikasi HEC-RAS yang menunjukkan bahwa elevasi muka air banjir melebihi elevasi full bank capacity. Untuk analisis perencanaan desain transportasi sungai, berdasarkan hasil analisis parameter kedalaman, lebar satu dan dua jalur, kedalaman kolam putar, dan diameter kolam manuver, desain kapal yang direkomendasikan untuk berlayar di Sungai Bengawan Solo di bagian hilir di Kota Bojonegoro adalah kapal barang dan penumpang dengan draft 0,6 meter dan LOA 18 meter atau kapasitas penumpang sebanyak 70 orang per kapal.
\end{abstract}

Kata-kata kunci: banjir, HSS Nakayasu, HEC-RAS, transportasi sungai

\section{Pendahuluan}

Bencana banjir merupakan bencana yang sering terjadi di wilayah Indonesia ini. Permasalahan banjir mengakibatkan kerugian secara materi, dan banjir menimbulkan kesan ketidaknyamanan dan mengganggu aktivitas sehingga mengganggu pertumbuhan kota. Banjir terdiri dari berbagai jenis banjir seperti banjir air, banjir cileuncang, banjir bandang, banjir rob, banjir lahar dingin dan banjir lumpur. Bencana banjir dapat diakibatkan oleh faktor alam dan juga disebabkan karena ulah manusia itu sendiri. Bencana banjir dapat juga disebabkan faktor-faktor akibat luapan Sungai, sistem drainasi yang buruk, dari rusaknya ekologis, yang didalamnya akibat pembabatan hutan, legal maupun ilegal dan lain-lain. Ketika musim hujan datang, beberapa langkah prevensi telah 
direncanakan. Namun, alam selalu memiliki kekuatan tidak terduga. Schanze (2006) dan Merz et al (2007) menyimpulkan bahwa banjir merupakan kenaikan muka air yang tidak diinginkan yang diakibatkan oleh kegagalan bendungan atau durasi hujan yang lama dengan intensitas tinggi.

Selain permasalahan banjir, salah satu fokus permasalahan dalam studi kasus ini adalah adanya Sungai Bengawan Solo yang potensial untuk dimanfaatkan sebagai sarana transportasi air. Transportasi adalah pemindahan fisik baik barang maupun orang, dari suatu tempat ke tempat lain (Subiyakto dan Suryo , 2001). Transportasi adalah hal yang menyangkut peningkatan kualitas hidup masyarakat banyak. Sebab, sistem transportasi memiliki pengaruh besar pada tingkat mobilitas individu yang akhirnya berdampak pada kehidupan ekonomi masyarakat. Sistem transportasi masal yang tertata dengan tertib dan nyaman merangsang anggota masyarakat untuk mengembangkan potensi yang dimilikinya.

Menurut Subiyakto dan Suryo (2001), kalangan sejarawan dan geograf acapkali menyatakan bahwa pelayanan sungai pada masa dahulu merupakan hal penting bagi berlangsungnya kegiatan perekonomian suatu masyarakat. Sehingga, adanya transportasi sungai ini sebagai bahan atau kajian dasar untuk perencanaan transportasi sungai di Bojonegoro untuk mendukung perekonomian masyarakat.

\section{Metode}

Penelusuran banjir adalah perkiraan waktu dan besaran banjir di suatu titik aliran sungai dengan titik yang lain. Tujuan dari penelusuran banjir adalah untuk memperkirakan banjir jangka pendek dan memperkirakan kelakuan sungai setelah terjadi perubahan akibat pembangunan seperti pembangunan tanggul (Limantara, 2010). Hidrograf banjir dibutuhkan untuk mengetahui informasi tentang debit banjir yang terjadi pada lokasi yang ditinjau. Sehingga, besarannya aliran sungai pada suatu waktu dapat dianalisis. Dalam hal penelusuran banjir (flood routing), hidrograf banjir dipandang sebagai prosedur yang dibutuhkan untuk menentukan hidrograf suatu titik di hilir dari hidrograf yang ditentukan dari titik di hulu (Susilowati, 2007).

Tahapan dalam kajian Analisis Banjir dan Perencanaan Transportasi Sungai di Bojonegoro adalah sebagai berikut:

Tahapan yang pertama adalah studi literatur dari berbagai jurnal, laporan studi kelayakan, laporan riset, peraturan pemerintah dan publikasi lainnya. Studi literatur juga bertujuan untuk mendapatkan benchmarking dari implementasi sistem yang sama dimana telah dilakukan oleh beberapa negara sebelumnya, sehingga diharapkan akan mampu menciptakan inovasi yang handal.

Kemudian pengumpulan data sekunder dari Balai Besar Wilayah Sungai Bengawan Solo berupa data hidrologi.

Tahapan berikutnya adalah analisis banjir. Pada tahap ini model hidrologi digunakan untuk melakukan simulasi debit puncak dan mendesain hidrograf banjir. Ada beberapa metode dalam menganalisis debit banjir di suatu daerah aliran sungai (DAS). Nigussie (2016) menggunakan metode hidrograf satuan sintesis (HSS) Snyder's, Soil Conservation Service (SCS), Mockus, Nakayasu, Rodriguez-Valdez, dan GuptaWaymire. Jeong dan Mun (2011) menggunakan metode rasional, USDA Soil Conservation Service (SCS), dan Nakayasu. Selain itu, Kang (2009) menggunakan metode rasional, WFRP, Nakayasu, SCS, dan Clark. Rivera (2007) melakukan pemodelan hidrologi menggunakan HEC-RAS (Hydrological Engineering Center-River Analysis System). Dengan metode yang sama, Paringit (2015) menggunakan HEC-RAS untuk menganalisis outflow dengan mempertimbangkan kekasaran permukaan. Dalam penelitian ini, akan dilakukan dua tahap metode analisis, yaitu analisis menggunakan metode debit banjir rancangan HSS Nakayasu, dibandingkan dengan kapasitas sungai yang tersedia, dan analisis menggunakan software HEC-RAS untuk mengetahui penyebab banjir di wilayah Bojonegoro.

Tahapan terakhir adalah analisis desain perencanaan dan kelayakan inovasi transportasi sungai. Pada tahap ini dilakukan analisis jenis kapal yang direkomendasikan berlayar berdasarkan parameter seperti kedalaman, lebar satu dan dua jalur, turning basin, dan kedalaman kolam putar. Selain itu, dianalisis rencana titik dermaga.

\section{Data curah hujan}

Stasiun penakar hujan yang secara khusus dipasang di lokasi perencanaan tidak tersedia, baik penakar hujan harian maupun otomatis. Stasiun hujan terdekat yang relevan digunakan di lokasi perencaaan adalah Stasiun Penakar Hujan Semarang, Stasiun Penakar Hujan Yogyakarta, Dan Stasiun Penakar Hujan Sawahan (Nganjuk). Walaupun letaknya relatif jauh, namun berada di kawasan yang sama yaitu kawasan pantai, maka karakteristik hujannya tidak jauh berbeda dengan 
lokasi perencanaan. Pada stasiun ini terdapat penakar hujan harian.

\section{Analisis banjir}

Data curah hujan diukur dengan penakar hujan yang berupa data curah hujan titik (point rainfall). Untuk mendapatkan data curah hujan rata-rata DAS dapat dihitung menggunakan Metode Thiessen (Harto, 1993; Ningsih, 2012; Kurniawati, 2005; Tella, 2005; Djafar et al., 2014; Dermawan et al., 2012; Robot dkk, 2014). Cara ini didasarkan atas rata-rata timbang, di mana masingmasing stasiun mempunyai daerah pengaruh yang dibentuk dengan garis-garis sumbu tegak lurus terhadap garis penghubung antara dua stasiun dengan planimeter, sehingga dapat dihitung luas daerah tiap stasiun (Sosrodarsono, 1999). Gambar 1 merupakan ilustrasi penggunaan metode Thiessen dengan enam stasiun hujan dalam suatu daerah tangkapan air.

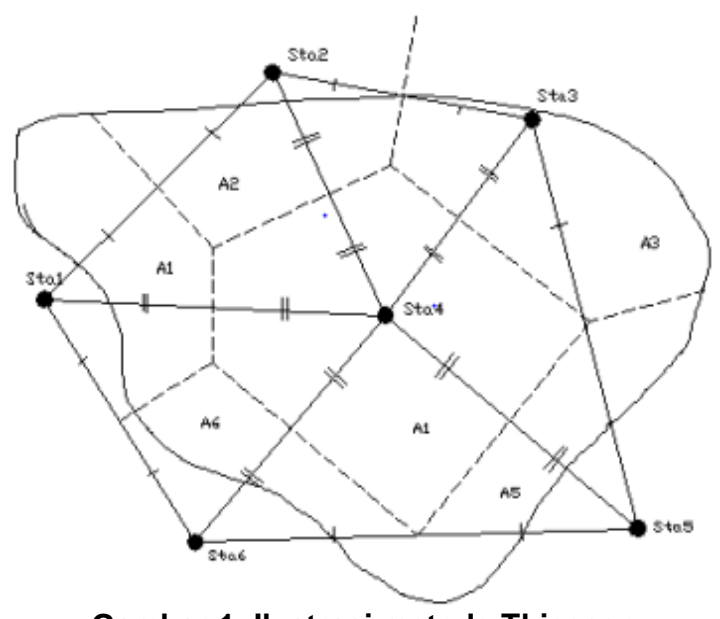

Gambar 1. Ilustrasi metode Thiessen

Dalam penelusuran banjir, digunakan Metode HSS Nakayasu. Persamaan 1 merupakan rumus dari hidrograf satuan Nakayasu.

$$
Q p=\frac{C \cdot A \cdot R o}{3,6\left(0,3 T p+T_{0,3}\right)}
$$

Dimana $Q p=$ debit puncak banjir $\left(\mathrm{m}^{3} / \mathrm{dt}\right)$, $\mathrm{Ro}=$ hujan satuan $(\mathrm{mm}), \mathrm{Tp}=$ tenggang waktu dari permulaan hujan sampai puncak banjir (jam), $\mathrm{T}_{0,3}=$ waktu yang diperlukan oleh penurunan debit, dari puncak sampai 30\% dari debit puncak (jam), dan $\mathrm{A}=$ luas daerah pengaliran sampai outlet $\left(\mathrm{km}^{2}\right)$.

Untuk menentukan $\mathrm{Tp}$ dan $\mathrm{T}_{0,3}$ digunakan pendekatan melalui Persamaan 2, Persamaan 3, dan Persamaan 4.

$$
\begin{aligned}
& T p=t g+0,8 t r \\
& T_{0,3}=\alpha t g \\
& \operatorname{Tr}=0,5 \text { tg sampai tg }
\end{aligned}
$$

tg adalah time lag yaitu waktu antara hujan sampai debit puncak banjir (jam). tg dihitung dengan ketentuan: (a) sungai dengan panjang alur $\mathrm{L}>15 \mathrm{~km}$, maka tg=0,4 + 0,058 L, (b) sungai dengan panjang alur $\mathrm{L}<15 \mathrm{~km}$, maka $\operatorname{tg}=0,21 \mathrm{~L}^{0,7}$. Nilai $\alpha$ (koefisien limpasan) diperoleh dengan Persamaan 5 (Soemarto,1999):

$$
\alpha=0,47 / \operatorname{tg}(A x L) x 0,25
$$

Dimana $\alpha=$ koefisien pembagian kecepatan aliran, $\mathrm{A}=$ luas DAS $\left(\mathrm{km}^{2}\right), \mathrm{L}=$ panjang sungai utama (km). Perhitungan $\mathrm{T}_{0,3}$ menggunakan ketentuan: $\alpha$ $=2$ pada daerah pengaliran biasa, $\alpha=1,5$ pada bagian naik hidrograf lambat, dan turun cepat, dan $\alpha=3$ pada bagian naik hidrograf cepat, dan turun lambat.

Ilustrasi penggambaran grafik hasil metode HSS Nakayasu dapat dilihat pada Gambar 2.

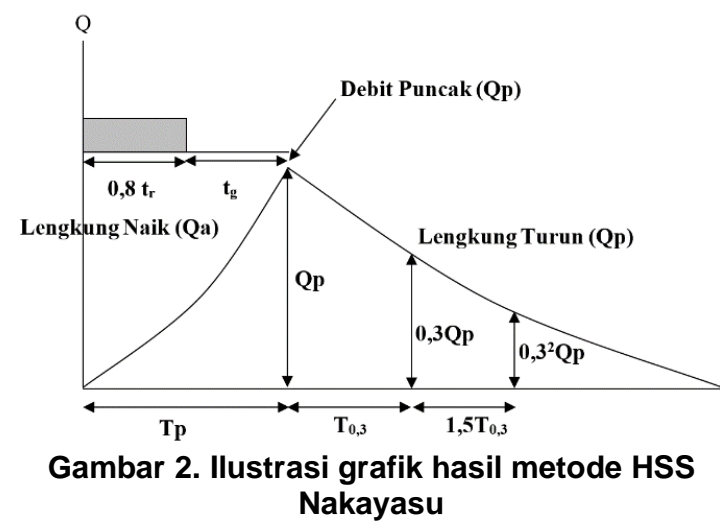

\section{Analisis kapasitas sungai}

Berdasarkan Suripin (2011), Sara (2011), Febriana (2009), Harseno (2007), Rahayu (2016), dan Al Amin (2013), perhitungan kapasitas sungai dari lokasi yang ditinjau menggunakan rumus Manning yang dijabarkan pada Persamaan 6.

$$
Q=A x R^{2 / 3} x S^{1 / 2} x n
$$

Dimana: $\mathrm{Q}=$ Kapasitas debit $\left(\mathrm{m}^{3} / \mathrm{s}\right)$ dan $\mathrm{n}=$ Koefisien kekasaran Manning. Dalam menentukan koefisien kekasaran manning melalui dimensi saluran, maka n ekivalen dapat ditentukan melalui Persamaan 7. 
$n_{\text {ekivalen }}=\left[\frac{\sum_{I-1}^{N} P_{i} n_{i} \frac{3}{2}}{P}\right]^{2 / 3}$

Dimana $\mathrm{R}=$ Radius hidrolik $(\mathrm{m}), \quad \mathrm{R}=\mathrm{A} / \mathrm{P}, \mathrm{S}$ $=$ Kemiringan dasar saluran, $\mathrm{A}=$ Luas penampang basah $\left(\mathrm{m}^{2}\right) \mathrm{A}_{\text {trapesium }}=\mathrm{B} \times(\mathrm{H}+2 \mathrm{~B})$, dan $\mathrm{P}=$ Keliling penampang basah $(\mathrm{m})$ di mana $\mathrm{P}_{\text {trapesium }}=$ $\mathrm{B}+2\left(\mathrm{H} \times\left(1+\mathrm{m}^{2}\right)^{1 / 2}\right)$.

\section{Analisis aplikasi HEC-RAS}

Berdasarkan analisis desain penampang sungai di berbagai wilayah yang telah dilakukan oleh Utami (2016) di Sungai Way Besai, Irawan (2014) di Saluran Kencong Timur, Apriliansyah (2014) di Bendung Gerak Karangtalun, secara garis besar, prosedur penggunaan program ini adalah (1) memasukkan data geometri sungai, (2) memasukkan data steady flow, (3) memasukkan debit banjir rancangan.

\section{Analisis perencanaan desain transportasi sungai}

Lebar alur pelayaran

Tahapan analisis dilakukan berdasarkan penelitian yang pernah dilakukan oleh Kadarsa (2015). Belum ada persamaan baku yang digunakan untuk menghitung lebar alur tetapi telah ditetapkan berdasarkan lebar kapal dan faktor faktor yang ada. Jika kapal bersimpangan maka lebar alur yang digunakan minimum adalah $3-4$ lebar kapal.

Pada Gambar 3a, B = lebar kapal (m), A = lebar lintasan manuver kapal $=1,8 \mathrm{~B}(\mathrm{~m})$, dan $\mathrm{D}=$ ruang bebas minimum di bawah lunas kapal (keel) (m). Sedangkan Gambar 3b, lebar alur $=1,5 \mathrm{~B}+1,8 \mathrm{~B}+$ $\mathrm{C}+1,8 \mathrm{~B}+1,5 \mathrm{~B}$. Dengan keterangan $\mathrm{B}=$ lebar kapal (m), A = lebar lintasan manuver

kapal= 1,8B $(\mathrm{m}), \mathrm{C}=$ ruang bebas antara lintasan manuver kapal = B (m), D = ruang bebas minimum di bawah lunas kapal (keel) (m), dan kedalaman maksimum yang ditoleransi ketika berpapasan adalah $1,5 \mathrm{D}$.

\section{Kedalaman alur pelayaran}

Berdasarkan Kadarsa (2015), kedalaman alur pelayaran sungai dan danau adalah jarak antara permukaan perairan sungai dan danau pada posisi air surut terendah (LWS) dengan bagian dasar perairan. Untuk mendapatkan kondisi yang ideal, kedalaman air di alur pelayaran harus cukup untuk memungkinkan pelayaran pada muka air terendah (LWS) dengan kapal bermuatan maksimum.

Selain itu kedalaman alur pelayaran harus memperhatikan jarak toleransi dari gerakan kapal yang disebabkan oleh timbulnya gelombang, gerakan kapal dan kondisi dasar perairan. Secara umum kedalaman alur pelayaran dapat ditentukan dengan Persamaan 8.

$$
H=D+\sum t
$$

Di mana $\Sigma \mathrm{t}=\mathrm{t}_{1}+\mathrm{t}_{2}+\mathrm{t}_{3}+\mathrm{t}_{4}, \mathrm{H}=$ kedalaman alur sungai yang layak bagi pelayaran, $\mathrm{D}=d r a f t$ kapal, $\mathrm{t}_{1}$ adalah angka keamanan navigasi di bawah lunas kapal berdasarkan jenis tanah dasar alur sungai dan danau. Nilai $\mathrm{t}_{1}$ seperti pada Tabel 1 .

Tabel 1. Angka keamanan navigasi dibawah lunas kapal

\begin{tabular}{lccc}
\hline \multirow{2}{*}{$\begin{array}{c}\text { Jenis } \\
\text { tanah }\end{array}$} & \multicolumn{3}{c}{$\begin{array}{c}\text { Angka keamanan berdasarkan } \\
\text { ukuran kapal }\end{array}$} \\
\cline { 2 - 4 } & $\begin{array}{c}\text { LOA }> \\
\mathbf{1 8 5} \text { meter }\end{array}$ & $\begin{array}{r}\mathbf{1 2 5}<\mathbf{L O A}< \\
\mathbf{1 8 5} \text { meter }\end{array}$ & $\begin{array}{c}\text { LOA }< \\
\mathbf{8 6} \text { meter }\end{array}$ \\
\hline Campuran & 0,20 & 0,20 & 0,200 \\
Pasir & & & \\
Pasir & 0,30 & 0,25 & 0,200 \\
Padat & 0,45 & 0,30 & 0,200 \\
Keras & 0,50 & 0,45 & 0,201 \\
\hline Sumber: Departemen Perhubungan, 2010 &
\end{tabular}

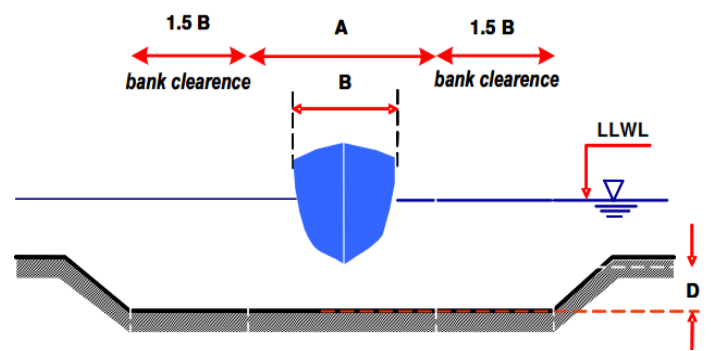

(a)

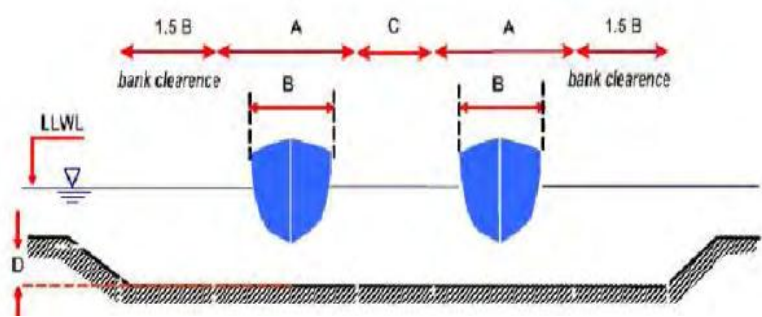

(b)

Gambar 3. (a) llustrasi lebar alur satu jalur dan (b) dua jalur 
$\mathrm{t}_{2}$ merupakan angka keamanan karena adanya timbulan gelombang. Nilai $t_{2}$ didapat melalui $t_{2}=$ $0,3 \mathrm{H}-\mathrm{t}_{1}$ dengan keterangan $\mathrm{H}$ adalah timbulan gelombang karena gerakan kapal. Timbulan gelombang dipengaruhi oleh kecepatan kapal dengan Bilangan Froude dibawah kecepatan kritis $(\mathrm{Fn}<1)$ disajikan pada Tabel 2.

Jika $t_{2}$ adalah negatif, maka $t_{2}$ dianggap nol $\left(\mathrm{t}_{2}=\right.$ $0)$. $t_{3}$ adalah angka keamanan yang disebabkan oleh gerakan kapal yang didapat melalui $t_{3}=k \cdot v$ dengan $\mathrm{v}=$ kecepatan $\mathrm{kapal}(\mathrm{km} / \mathrm{jam})$ dan $\mathrm{k}=$ koefisien yang tergantung ukuran kapal sebagaimana pada Tabel 3 berikut. $t_{4}$ merupakan angka keamanan untuk pekerjaan pengerukan alur, nilainya $\pm 0,40$ meter.

Tabel 2. Angka keamanan akibat timbulan gelombang

\begin{tabular}{crrc}
\hline \multicolumn{2}{c}{ Kecepatan } & \multirow{2}{*}{ Fn } & $\begin{array}{c}\text { Tinggi gelombang } \\
\text { maksimum (meter) }\end{array}$ \\
\cline { 1 - 3 } knot & Km/jam & & (m, \\
\cline { 1 - 3 } 2 & 3,704 & 0,1401 & 0,0014 \\
3 & 5,556 & 0,2101 & 0,0022 \\
4 & 7,408 & 0,2801 & 0,0051 \\
5 & 9,260 & 0,3502 & 0,0722 \\
6 & 11,112 & 0,4201 & 0,2860 \\
7 & 12,964 & 0,4902 & 0,4324 \\
8 & 14,816 & 0,5603 & 0,4019 \\
9 & 16,668 & 0,6303 & 0,7229 \\
10 & 18,52 & 0,7004 & 0,9847 \\
11 & 20,372 & 0,7704 & 1,3089 \\
12 & 22,224 & 0,8404 & 1,2008 \\
13 & 24,076 & 0,9105 & 1,4003 \\
14 & 25,928 & 0,9805 & 1,5998 \\
15 & 27,780 & 1,0506 & 1,7867 \\
\hline \multicolumn{3}{c}{ Sumber: Departemen perhubungan, 2010 }
\end{tabular}

Tabel 3. Angka keamanan yang disebabkan oleh gerakan kapal

\begin{tabular}{ccccc}
\hline $\begin{array}{c}\text { Ukuran } \\
\text { Kapal }\end{array}$ & $\begin{array}{c}\text { LOA } \\
>\mathbf{1 8 5} \\
\text { meter }\end{array}$ & $\begin{array}{c}\mathbf{1 2 5} \\
<\text { LA }<\mathbf{1 8 5} \\
\text { meter }\end{array}$ & $\begin{array}{c}\text { LOA } \\
<\mathbf{8 6} \\
\text { meter }\end{array}$ & $\begin{array}{c}\mathbf{1 2 5} \\
<\mathbf{L A}<\mathbf{8 6} \\
\text { meter }\end{array}$ \\
\hline Koefisien & 0,033 & 0,027 & 0,022 & 0,017 \\
\hline \multicolumn{4}{l}{ Sumber: Departemen Perhubungan, 2010}
\end{tabular}

Perencanaan dimensi dermaga

Untuk menentukan panjang dermaga yang akan dibangun digunakan persamaan sebagai berikut:

$$
\begin{aligned}
& L p=n x L o a+(n-1) x 15+(2 \times 25) \\
& d=(L p-2 e) \\
& b=\frac{3 A}{d-2 e}
\end{aligned}
$$

Dimana $\mathrm{Lp}=$ panjang dermaga $(\mathrm{m}), \mathrm{A}=$ luas gudang $\left(\mathrm{m}^{2}\right), \mathrm{n}=$ jumlah kapal yang bertambat, Loa $=$ panjang kapal $(\mathrm{m}), \mathrm{b}=$ lebar gudang $(\mathrm{m})$, $\mathrm{a}=$ lebar apron $(\mathrm{m})$, e = lebar jalan $(\mathrm{m})$, dan $\mathrm{d}=$ panjang gudang $(\mathrm{m})$. Ilustrasi penerapan perhitungan Persamaan 9, Persamaan 10, dan Persamaan 11 dapat divisualisasikan seperti Gambar 4.

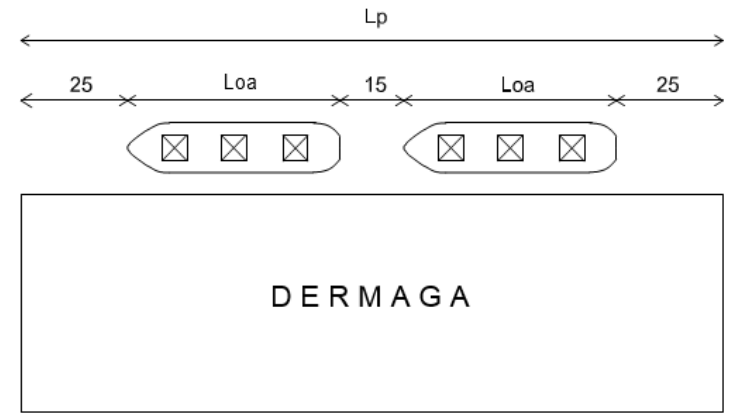

Gambar 4. Ilustrasi desain panjang dermaga

Perhitungan kolam putar

Kolam putar (turning basin) dibutuhkan sebagai area untuk manuver kapal sebelum dan sesudah bertambat. Berdasarkan Quinn (1972) ukuran kolam putar pelabuhan adalah 4 kali LoA. Rumus lain adalah $\mathrm{A}_{\mathrm{TB}}=\pi \times(1,5 \times \mathrm{LOA})^{2}$ atau $\mathrm{A}_{\text {lingkaran }}=$ $\left(\pi \times d^{2}\right) / 4$.

\section{Hasil dan Pembahasan}

Secara umum analisis hidrologi merupakan satu bagian analisis awal dalam perancangan bangunanbangunan hidraulik. Analisis hidrologi diperlukan untuk mengetahui karakteristik hidrologi di lokasi DAS Bengawan Solo sampai Kabupaten Bojonegoro. Analisis hidrologi digunakan untuk menentukan besarnya debit banjir rencana. Berdasarkan hasil analisis GIS, lokasi tinjauan penelitian ini memiliki luas DAS $=11056,71 \mathrm{~km}^{2}$ dan panjang sungai $=315099 \mathrm{~m}$.

\section{Analisis metode Thiessen}

DAS Bengawan Solo bagian hulu memiliki 3 stasiun hujan terdekat seperti diilustrasikan pada Gambar 5 untuk digunakan dalam analisis metode Thiessen. Setelah terbentuk polygon Thiessen, ditentukan luas pengaruh setiap daerah stasiun hujan pada DAS seperti yang tersaji di Tabel 4 . Sedangkan Tabel 5 merupakan data hujan maksimum rata-rata DAS dari masing-masing stasiun hujan.

Tabel 4. Luas pengaruh tiap stasiun hujan pada DAS

\begin{tabular}{cccc}
\hline $\begin{array}{c}\text { Presentase } \\
\text { luas (\%) }\end{array}$ & Stasiun & Luas $\left(\mathbf{K m}^{\mathbf{2}}\right)$ & $\begin{array}{c}\text { Luas / luas } \\
\text { DAS total }\end{array}$ \\
\hline 13,26 & Semarang & 1466,1198 & 0,1326 \\
39,12 & Jogja & 4325,3850 & 0,3912 \\
47,62 & Sawahan & 5265,2053 & 0,4762 \\
\hline
\end{tabular}


Tabel 5. Hujan maksimum rata-rata DAS Bengawan Solo sampai Kabupaten Bojonegoro

\begin{tabular}{rrrr}
\hline \multirow{2}{*}{ Tahun } & \multicolumn{3}{c}{ Stasiun Hujan } \\
& Yogya & Semarang & Sawahan \\
\hline 2004 & 106,0 & 85,0 & 102,0 \\
2005 & 98,0 & 98,0 & 165,0 \\
2006 & 131,5 & 152,0 & 77,0 \\
2007 & 117,8 & 108,0 & 150,0 \\
2008 & 102,0 & 119,0 & 215,5 \\
2009 & 85,0 & 235,0 & 180,0 \\
2010 & 131,0 & 139,0 & 156,0 \\
2011 & 81,0 & 106,0 & 182,0 \\
2012 & 118,0 & 110,0 & 123,0 \\
2013 & 131,3 & 146,5 & 128,0 \\
2014 & 85,3 & 141,7 & 147,5 \\
2015 & 73,9 & 71,0 & 130,0 \\
\hline
\end{tabular}

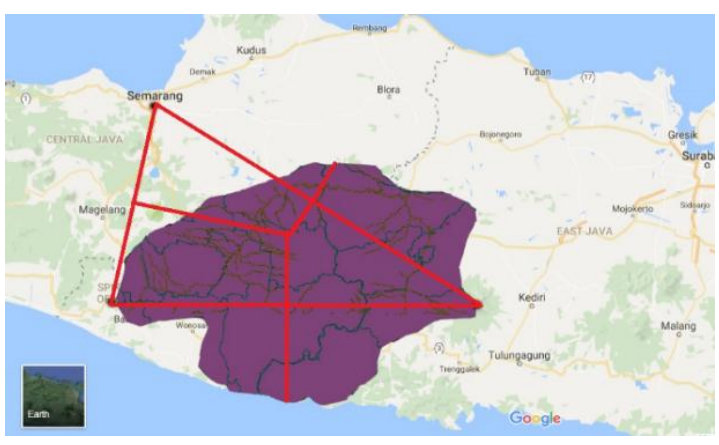

Gambar 5. Poligon Thiessen dari stasiun pengamatan curah hujan wilayah DAS Bengawan Solo sampai Kabupaten Bojonegoro

\section{Koefisien pengaliran}

Analisis perhitungan menghasilkan koefisien terbobot untuk hujan kala ulang. Untuk kala ulang 5 tahun sebesar 0,3306; kala ulang 10 tahun sebesar 0,3541, kala ulang 25 tahun sebesar 0,3925 , kala ulang 50 tahun sebesar 0,4259, dan kala ulang 100 tahun sebesar 0,4667.

\section{Analisis HSS Nakayasu}

Dalam pemilihan koefisien $\alpha$, dianalisis $\alpha=1,5 ; 2$; dan 3 dan dipilih yang menghasilkan hujan satuan mendekati hujan satuan ideal, yaitu $1 \mathrm{~mm}$. Hasil analisis berupa grafik hidrograf satuan pada DAS Bengawan Solo dapat dilihat pada Gambar 6. Hasil perhitungan hujan satuan secara urut adalah
0,88 $\mathrm{mm}, 0,82 \mathrm{~mm}$, dan $0,70 \mathrm{~mm}$. Sehingga, dipilih $\alpha=1,5$

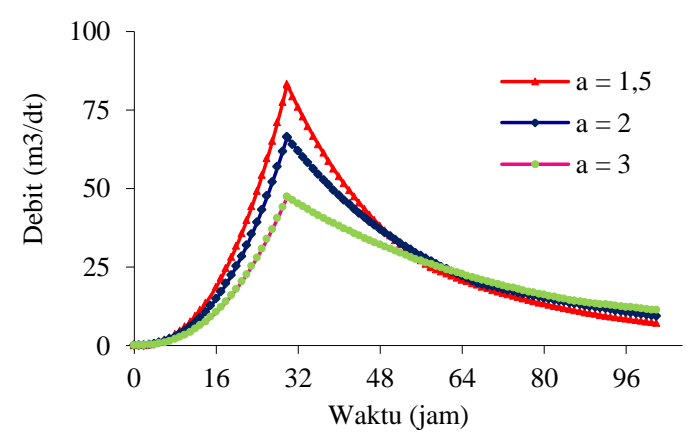

\section{Gambar 6. Grafik hidrograf satuan DAS Bengawan Solo}

Selanjutnya, dilakukan analisis debit rencana. Gambar 7 menunjukkan hasil analisis debit rencana menggunakan metode HSS Nakayasu untuk debit rencana kala ulang 5, 10, 25, 50, dan 100 tahun. Berdasarkan analisis menggunakan HSS Nakayasu, maka debit rencana kala ulang tersebut berturut-turut seperti yang tersaji di Tabel 6 adalah 3750,98 $\mathrm{m}^{3} / \mathrm{dt} ; 4242,70 \mathrm{~m}^{3} / \mathrm{dt} ; 4969,26$ $\mathrm{m}^{3} / \mathrm{dt} ; 5579,20 \mathrm{~m}^{3} / \mathrm{dt}$; dan $6297,57 \mathrm{~m}^{3} / \mathrm{dt}$.

Tabel 6. Hasil debit banjir rencana

\begin{tabular}{cc}
\hline $\begin{array}{c}\text { Kala ulang } \\
\text { (tahun) }\end{array}$ & $\begin{array}{c}\text { Q rencana } \\
\left(\mathbf{m}^{\mathbf{3}} / \mathbf{d t}\right)\end{array}$ \\
\hline 5 & 3750,98 \\
10 & 4242,70 \\
25 & 4969,26 \\
50 & 5579,20 \\
100 & 6297,57 \\
\hline
\end{tabular}

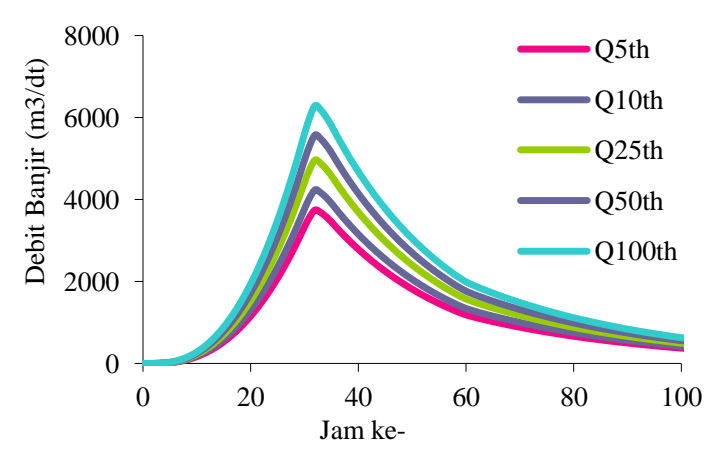

Gambar 7. Grafik hidrograf banjir DAS Bengawan Solo

Tabel 7. Perhitungan kapasitas sungai

\begin{tabular}{cccccc}
\hline $\mathbf{H}(\mathbf{m})$ & $\left.\mathbf{A ~} \mathbf{( m}^{\mathbf{2}}\right)$ & $\mathbf{P}(\mathbf{m})$ & $\mathbf{R}(\mathbf{m})$ & $\mathbf{V}(\mathbf{m} / \mathbf{s})$ & $\mathbf{Q t a m p u n g a n}\left(\mathbf{m}^{\mathbf{3}} / \mathbf{s}\right)$ \\
\hline 10,0 & 1900,00 & 208,2843 & 9,1221 & 1,8974 & 3605,1352 \\
9,5 & 1800,25 & 206,8701 & 8,7023 & 1,8388 & 3310,2400 \\
9,0 & 1701,00 & 205,4558 & 8,2792 & 1,7787 & 3025,5063 \\
8,5 & 1602,25 & 204,0416 & 7,8526 & 1,7170 & 2751,1091 \\
8,0 & 1504,00 & 202,6274 & 7,4225 & 1,6537 & 2487,2387 \\
7,5 & 1406,25 & 201,2132 & 6,9889 & 1,5887 & 2234,1026 \\
\hline
\end{tabular}


Tabel 8. Hasil profil aliran di Sta.98, Sta.49 dan Sta.0

\begin{tabular}{|c|c|c|c|c|c|c|c|c|}
\hline Sungai & $\begin{array}{c}\text { Sta. } \\
\text { sungai }\end{array}$ & $\begin{array}{c}\text { Kala } \\
\text { ulang } \\
\text { (tahun) }\end{array}$ & $\begin{array}{c}\text { Debit } \\
\text { total } \\
\left(\mathbf{m}^{3} / \mathbf{s}\right)\end{array}$ & $\begin{array}{c}\text { Elevasi } \\
\text { dasar } \\
\text { sungai } \\
\text { (m) }\end{array}$ & $\begin{array}{c}\text { Elevasi } \\
\text { banjir } \\
(\mathbf{m})\end{array}$ & $\begin{array}{c}\text { Kecepatan } \\
\text { saluran } \\
(\mathbf{m} / \mathbf{s})\end{array}$ & $\begin{array}{c}\text { Elevasi } \\
\text { fullbank } \\
\text { plus } \\
\text { tinggi } \\
\text { Jagaan }\end{array}$ & $\begin{array}{c}\text { Tinggi } \\
\text { limpasan } \\
\text { (m) }\end{array}$ \\
\hline Bengawan Solo bagian hulu & 98 & 5 & 3750,98 & 0 & 13,85 & 1,23 & 13,33 & $-0,52$ \\
\hline Bengawan Solo bagian hulu & 98 & 10 & 4242,70 & 0 & 14,50 & 1,30 & 13,33 & $-1,17$ \\
\hline Bengawan Solo bagian hulu & 98 & 25 & 4969,26 & 0 & 15,41 & 1,39 & 13,33 & $-2,08$ \\
\hline Bengawan Solo bagian hulu & 98 & 50 & 5579,20 & 0 & 16,11 & 1,46 & 13,33 & $-2,78$ \\
\hline Bengawan Solo bagian hulu & 98 & 100 & 6297,57 & 0 & 16,89 & 1,54 & 13,33 & $-3,56$ \\
\hline Bengawan Solo bagian tengah & 49 & 5 & 3750,98 & 0 & 12,07 & 1,59 & 13,33 & 1,26 \\
\hline Bengawan Solo bagian tengah & 49 & 10 & 4242,70 & 0 & 12,74 & 1,69 & 13,33 & 0,59 \\
\hline Bengawan Solo bagian tengah & 49 & 25 & 4969,26 & 0 & 13,65 & 1,71 & 13,33 & $-0,32$ \\
\hline Bengawan Solo bagian tengah & 49 & 50 & 5579,20 & 0 & 14,29 & 1,80 & 13,33 & $-0,96$ \\
\hline Bengawan Solo bagian tengah & 49 & 100 & 6297,57 & 0 & 14,99 & 1,90 & 13,33 & $-1,66$ \\
\hline Bengawan Solo bagian hilir & 0 & 5 & 3750,98 & 0 & 3,74 & 5,86 & 13,33 & 9,59 \\
\hline Bengawan Solo bagian hilir & 0 & 10 & 4242,70 & 0 & 4,05 & 6,09 & 13,33 & 9,28 \\
\hline Bengawan Solo bagian hilir & 0 & 25 & 4969,26 & 0 & 4,48 & 6,39 & 13,33 & 8,85 \\
\hline Bengawan Solo bagian hilir & 0 & 50 & 5579,20 & 0 & 4,83 & 6,62 & 13,33 & 8,5 \\
\hline Bengawan Solo bagian hilir & 0 & 100 & 6297,57 & 0 & 5,23 & 6.86 & 13,33 & 8,1 \\
\hline
\end{tabular}

\section{Analisis kapasitas sungai}

Berdasarkan analisis kapasitas sungai pada Tabel 7, kapasitas maksimum tampungan sungai yaitu $3605,1352 \mathrm{~m}^{3} / \mathrm{s}$. Hasil tersebut dibandingkan dengan debit banjir kala ulang pada Tabel 6 . Berdasarkan hasil perhitungan dan perbandingan antara debit rancangan banjir versus debit tampungan sungai dengan debit banjir rencana kala ulang 5, 10, 25, 50, 100 tahun, maka, Sungai Bengawan Solo bagian hilir tidak dapat menampung debit banjir yang ada, sehingga debit meluap dan menyebabkan banjir.

\section{Analisis profil aliran menggunakan HEC-RAS}

Dari hasil pembahasan pada potongan titik yang ditinjau pada bagian hilir (sta.0) debit banjir masih aman (belum melimpas), untuk bagian tengah (sta.49) untuk kala ulang banjir 25, 50 dan 100 tahun sudah mulai melimpas, bagian hulu (sta.98) di semua kala ulang banjir melimpas semua. Lokasi Bojonegoro berada di titik cross section sta. 98. Hasil analisis ketiga titik analisis cross section tersaji pada Tabel 8. Gambar 8 dan Gambar 9 merupakan contoh hasil analisis profil aliran menggunakan HEC-RAS pada cross section sungai Bengawan Solo bagian hilir (di Bojonegoro) untuk debit rencana kala ulang 5 dan 10 tahun di sta. 98. Sedangkan Gambar 10 merupakan ilustrasi lokasi Sta. cross section yang berada di Sungai Bengawan Solo Bagian Hilir.

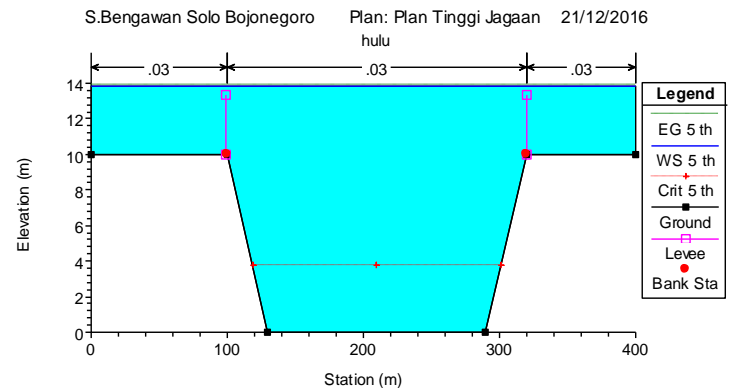

Gambar 8. Potongan sungai (hasil HEC-RAS) sta.98 kala ulang 5 tahun

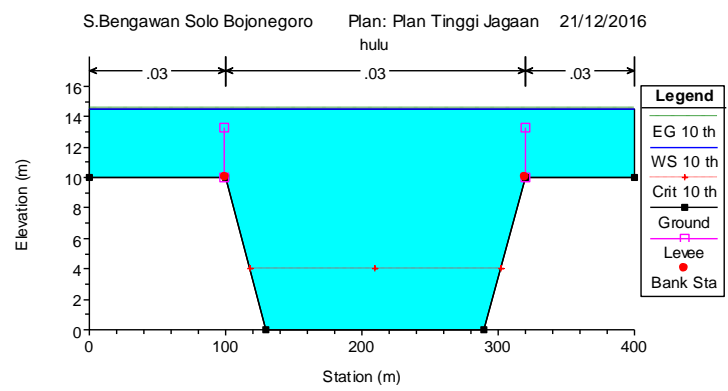

Gambar 9. Potongan sungai (hasil HEC-RAS) sta.98 kala ulang 10 tahun

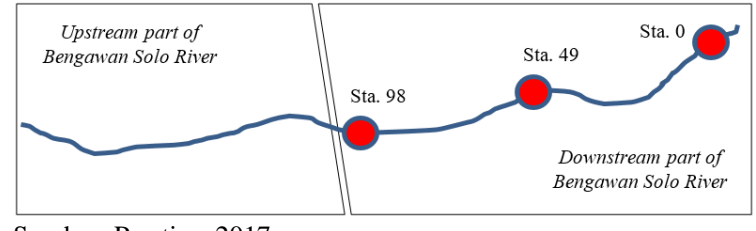

Sumber: Prastica, 2017

Gambar 10. Sketsa Lokasi sta. cross section 


\section{Analisis perencanaan desain transportasi sungai}

Alur pelayaran sungai yang menjadi kajian dalam penelitan ini adalah Sungai Bengawan Solo sejauh 47,7 kilometer di Kota Bojonegoro. Adapun data alur pelayaran sungai adalah panjang 47,7 km, lebar 200 meter, dan dasar campuran pasir.

Kedalaman alur sungai yang dibutuhkan untuk pelayaran ditentukan dengan uji coba (trial and error) untuk berbagai draft kapal. Untuk penentuan draft maksimum kapal yang dapat berlayar pada saat air surut terendah dicoba kapal dengan draft 0,60 meter untuk kapal barang dan penumpang dengan panjang masing-masing 18 meter (benchmarking kapal jenis fiber terbesar di Indonesia). Perbedaan kedua kapal terutama pada kecepatan berlayar dimana perbedaan tersebut mempengaruhi kedalaman yang dibutuhkan oleh kedua kapal walaupun draft dan panjang kapal sama. Analisis jenis kapal yang direncanakan pada penelitian ini adalah Kapal Penumpang Kapasitas 70 orang Seri JS 1843 dengan desain ukuran utama kapal adalah panjang 18,00 meter, lebar 4,30 meter, tinggi 1,80 meter, dan draft 0,60 meter.

\section{Kapal Barang}

- $\mathrm{D}($ draft $)=0,6$ meter dengan panjang kapal = 18 meter

- $\mathrm{t}_{1}=0,20$ berdasarkan Tabel 1 untuk LOA $<86$ dan jenis tanah di dasar sungai adalah campuran pasir.

- $\mathrm{t}_{2}=0,3 \mathrm{H}-\mathrm{t}_{1}=(0,3 \times 0,4324)-0,2=-$ 0,87028 . Nilai $t_{2}$ dianggap nol karena nilainya negatif. Nilai $\mathrm{H}$ ditentukan berdasarkan Tabel 2 dengan asumsi kecepatan kapal barang adalah 7 knot.

- $\mathrm{t}_{3}=\mathrm{k} \cdot \mathrm{v}=12,964 \mathrm{~km} / \mathrm{jam} \times 0,022=0,2852$ dimana $\mathrm{k}$ adalah kecepatan kapal dan $\mathrm{v}$ berdasarkan Tabel 3. Berdasarkan persamaan untuk memperoleh nilai $\mathrm{t}_{3}$ dan data Tabel 3, diketahui bahwa semakin rendah kecepatan kapal yang berlayar, maka semakin kecil kedalaman yang dibutuhkan.

- $\mathrm{t}_{4}=0,40$ yang merupakan angka keamanan untuk pekerjaan pengerukan alur.

Dengan menggunakan data perhitungan nilai $t_{1}$ sampai $\mathrm{t}_{4}$ dan $\mathrm{D}=0,6$ meter, maka kedalaman alur pelayaran sungai yang diperlukan agar kapal barang tersebut dapat berlayar dengan aman dan efisien ditentukan melalui persamaan $\mathrm{h}=\mathrm{D}+\sum$ t. Kedalaman yang dibutuhkan oleh kapal barang tersebut untuk berlayar di alur pelayaran Sungai Bengawan Solo sebesar 1,48 meter atau mendekati 1,50 meter. Diketahui bila kedalaman alur pelayaran pada saat air surut terendah ditetapkan 4 meter, maka kapal dengan draft sebesar 0,6 meter dapat berlayar dengan aman tanpa resiko kandas.

\section{Kapal Penumpang}

- $\mathrm{D}=0,6$ meter dengan panjang kapal $=18$ meter - $\mathrm{t} 1=0,20$ berdasarkan Tabel 1 untuk LOA < 86 dan jenis tanah di dasar sungai adalah campuran pasir.

- $\mathrm{t} 2=0,3 \mathrm{H}-\mathrm{t} 1=(0,3 \times 1,2008)-0,2=$ 0,16024 . Nilai H ditentukan berdasarkan Tabel 2 dengan asumsi kecepatan kapal penumpang adalah 12 knot.

- $\mathrm{t} 3=\mathrm{k} . \mathrm{v}=22,224 \mathrm{~km} / \mathrm{jam} \times 0,022=0,4889$ dimana $\mathrm{k}$ adalah kecepatan kapal dan $\mathrm{v}$ berdasarkan Tabel 3 .

- $\mathrm{t} 4=0,40$ yang merupakan angka keamanan untuk pekerjaan pengerukan alur.

Kedalaman yang dibutuhkan oleh kapal penumpang untuk berlayar di alur pelayaran Sungai Bengawan Solo sebesar 1,849 meter atau mendekati 2,00 meter. Untuk dapat berlayar pada saat air surut terendah 4 meter, maka kapal dengan draft sebesar 0,6 meter dapat berlayar dengan aman tanpa resiko kandas.

Berdasarkan dari perhitungan-perhitungan diatas diketahui alur pelayaran Sungai Bengawan Solo dapat dilayari sepanjang tahun selama 24 jam oleh kapal-kapal barang dan penumpang dengan draft 0,6 meter pada kedalaman air surut terendah 4 meter (kecepatan kapal $\leq 12$ knot).

Hasil analisis menunjukkan kedalaman yang dibutuhkan oleh jenis kapal barang adalah 1,5 meter sedangkan kapal penumpang 2 meter. Kedalaman saat air surut terendah adalah 4 meter. Sehingga, berdasarkan kedalaman yang dibutuhkan oleh kedua kapal yang dianalisis berada dalam kategori aman. Lebar kapal barang dan kapal penumpang adalah 4,3 meter. Dari hasil analisis, rencana lebar alur pelayaran yang dibutuhkan adalah 25,80 meter bila menggunakan analisis rencana alur satu jalur. Bila digunakan rencana lebar alur pelayaran dua jalur, dibutuhkan lebar sungai sebesar 30,10 meter. Berdasarkan kondisi lebar sungai eksisting, kedua kondisi tersebut masih memenuhi untuk kedua jenis kapal yang ditinjau. Kedalaman maksimum sungai yang ditoleransi ketika terdapat dua kapal berpapasan adalah 1,5D. Hasil analisis menunjukkan kapal barang membutuhkan 2,25 meter dan kapal penumpang 3,00 meter kedalaman rencana alur dua jalur. Dengan kondisi eksisting kedalaman saat air surut terendah adalah 4 meter, maka 
kondisi tersebut masih memenuhi syarat. Diameter desain kolam putar yang dibutuhkan untuk kedua jenis kapal adalah 72 meter dengan kedalaman kolam putar 0,7 meter. Dengan kondisi tersebut, kedua jenis kapal bias melakukan manuver dengan aman. Panjang perencanaan dermaga pada analisis tinjauan Sungai Bengawan Solo di Bojonegoro adalah 101 meter. Berdasarkan hasil perencanaan panjang antartitik dermaga, total panjang rencana rute transportasi sungai adalah 47,7 $\mathrm{km}$ dengan ilustrasi rute perjalanan kapal seperti yang tervisualisasi pada Gambar 11.

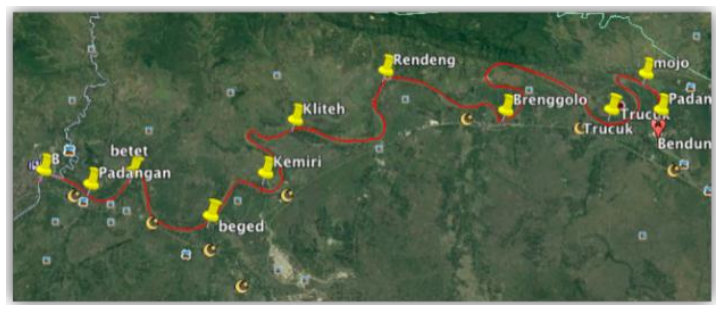

Gambar 11. Titik Dermaga Direncanakan

Berdasarkan hasil analisis di atas, maka simpulan desain kapal yang direkomendasikan untuk berlayar di Sungai Bengawan Solo di bagian hilir di Kota Bojonegoro adalah kapal barang dan penumpang dengan draft 0,6 meter atau kapasitas penumpang sebanyak 70 orang per kapal.

\section{Kesimpulan}

Berdasarkan hasil analisis yang telah dilakukan, maka berikut adalah kesimpulan dari hasil kajian Analisis Banjir dan Perencanaan Transportasi Sungai di Bojonegoro.

\section{Analisis Banjir}

Berdasarkan hasil analisis hidrologi, banjir disebabkan oleh:

(a) Debit rancangan melebihi kapasitas debit di sungai, sehingga meluap.

(b) Elevasi MAB melebihi elevasi full bank capacity berdasarkan analisis HEC-RAS.

\section{Analisis Perencanaan Transportasi Sungai} Berdasarkan hasil analisis parameter kedalaman, lebar satu dan dua jalur, kedalaman kolam putar, dan diameter kolam manuver, desain kapal yang direkomendasikan untuk berlayar di Sungai Bengawan Solo di bagian hilir di Kota Bojonegoro adalah kapal barang dan penumpang dengan draft 0,6 meter dan LOA 18 meter atau kapasitas penumpang sebanyak 70 orang per kapal.

Berdasarkan hasil kajian yang telah dilakukan, maka saran yang dapat kami berikan untuk bahan pertimbangan kebijakan Pemerintah Kota Bojonegoro atau pihak yang akan melakukan kajian lebih dalam selanjutnya, yaitu normalisasi sungai, perbaikan tanggul, analisis atau penelitian lebih detail dengan data yang lebih lengkap mengenai kajian banjir di Bojonegoro. Bila proyek transportasi sungai dijalankan, disarankan pemilihan jenis kapal disesuaikan dengan Standarisasi Kelayakan Alur Pelayaran Sungai dari Departemen Perhubungan Darat dan Peraturan Kenavigasian Sungai. Perlu dianalisis lebih dalam mengenai sedimentasi yang bisa menghambat aktivitas pergerakan kapal. Selain itu, sosialisasi kepada masyarakat mengenai program pemerintah untuk meminimumkan konflik horizontal dan vertikal.

\section{Ucapan Terima Kasih}

Terima kasih penyusun sampaikan kepada Prof. Dr. Ing. Ir. Dwita Sutjiningsih Dipl. HE dan Evi Anggraheni S.T., M.T. selaku fasilitator dalam membimbing terselesaikannya penyusunan penelitian ini. Penulis utama juga menyampaikan terima kasih kepada Lembaga Pengelola Dana Pendidikan (LPDP) yang telah memberikan dukungan moral dan materi. Makalah ini adalah bagian dari penelitian utama yang berjudul Estimating Design Flood and HEC-RAS Modeling Approach for Flood Analysis in Bojonegoro City yang dipresentasikan dalam konferensi internasional Quality in Research pada 24-27 Juli 2017 di Bali, Indonesia.

\section{Daftar Pustaka}

Al Amin, M. B., Ilmiaty, R. S., Hakki, H., \& Rizki, F. T. (2013). Kalibrasi Nilai Kekasaran Manning pada Saluran Terbuka Komposit (Fiber Bergelombang-Kaca) Terhadap Variasi Kedalaman Aliran (Kajian Laboratorium). Prosiding Seminar Nasional AVoER ke-5 di Fakultas Teknik Universitas Sriwijaya Palembang, 28 November 2013 ISBN 979-587-496-9.

Apriliansyah, Burhannudin, Heri Suprijanto, Mohammad Taufiq. (2014). Pemodelan Awal Perencanaan Bendung Gerak Karangtalun dengan HEC-RAS. Jurnal Pengairan Universitas Brawijaya.

Departemen Perhubungan. (2010). Laporan Akhir Studi Standarisasi di Bidang Lalu Lintas dan Angkutan Transportasi ASDP.

Dermawan, V., Hoesein, A. A., \& Firmansyah, W. (2012). Analisa Metode Kagan-Rodda Terhadap Analisa Hujan Rata-Rata dalam Menentukan Debit 
Banjir Rancangan dan Pola Sebaran Stasiun Hujan di Sub DAS Amprong. Jurnal Teknik Pengairan, 1(2), 67-75.

Djafar, H., Limantara, L. M., \& Asmaranto, R. (2015). Studi Analisa Kebutuhan Jumlah Stasiun Hujan Berdasarkan Evaluasi Perbandingan Antara Analisa Hidrograf Banjir Dan Banjir Historis Pada Das Limboto Provinsi Gorontalo. Jurnal Teknik Pengairan, 5(2), 172-181.

Febriana, Yudha. (2009). Analisis Sistem Drainase Medokan Terhadap Fluktuasi Debit Kali Wonokromo. Skripsi, Fakultas Teknik Departemen Teknik Sipil Universitas Indonesia.

Harseno, E., \& Jones, S. V. (2007). Studi Eksperimental Aliran Berubah Beraturan Pada Saluran Terbuka Bentuk Prismatis. Jurnal Ilmiah UKRIM, 2(12), 1-26.

Irawan, Erik Setyo. (2014). Analisis Pemodelan Sedimentasi di Saluran Kencong Timur (Beoddo) Menggunakan Program HEC-RAS. Skripsi, Jurusan Teknik Sipil Fakultas Teknik Universitas Jember.

Jeong, S. W., \& Mun, J. W. (2001). The comparison of existing synthetic unit hydrograph method in Korea. Journal of Korea Water Resources Association, 34(6), 659-672.

Kadarsa, Edi, dkk. (2015). Kajian Kelayakan Alur Pelayaran Pelabuhan Pontianak. The 18th FSTPT International Symposium, Universitas Lampung, Bandar Lampung, 28 Agustus 2015.

Kang, M. S., Koo, J. H., Chun, J. A., Her, Y. G., Park, S. W., \& Yoo, K. (2009). Design of drainage culverts considering critical storm duration. biosystems engineering, 104(3), 425-434.

Kurniawati, Atin. (2005). Perbandingan Metode Perhitungan Curah Hujan (Metode Aritmatik dan Mehode Thiessen) Terhadap Hasil Kalibrasi dan Validasi Model IHACRES. Skripsi, Jurusan Teknik Pertanian Fakultas Teknologi Pertanian Universitas Jember.

Limantara, Lily Montarcih. (2010). Hidrologi Praktis. Bandung: Lubuk Agung.

Merz, B., Thieken, A. H., \& Gocht, M. (2007). Flood risk mapping at the local scale: concepts and challenges. Flood risk management in Europe, 231-251.
Nigussie, T. A., Yeğen, E. B., \& Melesse, A. M. (2016). Performance Evaluation of Synthetic Unit Hydrograph Methods in Mediterranean Climate. A Case Study at Guvenc Micro-watershed, Turkey. In Landscape Dynamics, Soils and Hydrological Processes in Varied Climates (pp. 293-315). Springer International Publishing.

Ningsih, D. H. U. (2012). Metode Thiessen Polygon untuk Ramalan Sebaran Curah Hujan Periode Tertentu pada Wilayah yang Tidak Memiliki Data Curah Hujan. Dinamik-Jurnal Teknologi Informasi, 17(2).

Paringit, E.C. (2015). Automation of Cagayan de Oro River flood watch system using HEC-HMS and HECRAS. Proceedings of ACRS 2015 - 36th Asian Conference on Remote Sensing: Fostering Resilient Growth in Asia.

Prastica, Rian Mantasa Salve, Caya Maitri, Pratomo Cahyo Nugroho, Ade Hermawan, Dwita Sutjiningsih, Evi Anggraheni. (2017). Estimating Design Flood and HEC-RAS Modeling Approach for Flood Analysis in Bojonegoro City. Proceeding of the $15^{\text {th }}$ International Conference on Quality in Research, Nusa Dua, Bali, July $24^{\text {th }}-27^{\text {th }}, 2017$.

Rahayu, Cici Marlina. (2016). Analisis Energi Relativistik dan Fungsi Gelombang Persamaan Dirac untuk Potensial Radial Eckart Plus Manning Rosen yang Dikopling dengan Potensial Tensor Tipe-Coulomb untuk Exact Spin Simetri dan Exact Pseudospin Simetri Menggunakan Aim (Asymptotic Iteration Method). Skripsi, Jurusan Fisika Fakultas Matematika dan Ilmu Pengetahuan Alam Universitas Sebelas Maret.

Rivera, S., Hernandez, A. J., Ramsey, R. D., \& Suarez, G. (2007). Predicting flood hazard areas: a swat and HEC-RAS simulations conducted in Aguan river basin of Honduras, central America. In ASPRS 2007 Annual Conference (pp. 7-11).

Robot, J. A., Mananoma, T., Wuisan, E. M., \& Tangkudung, H. (2014). Analisis Debit Banjir Sungai Ranoyapo Menggunakan Metode HSS Gama-I dan HSS Limantara. Jurnal Sipil Statik, 2(1).

Quinn, Alonzo Def. (1972). Design \& Contruction of Part \& Marine Structures. Mc Graw-Hill Book Comp. 
Sara, Dinya Amima. (2011). Pengembangan Model Beda Hingga Dua Dimensi untuk Aliran Sungai dengan Program Visual Basic. Skripsi, Fakultas Teknik Departemen Teknik Sipil Universitas Indonesia.

Schanze, J. (2006). Flood risk management-a basic framework. Flood risk management: hazards, vulnerability and mitigation measures, 1-20. NATO Science Series, IV Earth and Environmental Sciences 67 Springer, Dordrecht, The Netherlands.

Soemarto, C.D. (1999). Hidrologi Teknik Edisi Kedua. Jakarta: Erlangga.

Sosrodarsono, Suyono dan Kensaku Takeda. (1999). Hidrologi untuk Pengairan. Jakarta: PT. Pradnya Paramita.

Subiyakto, B, dan Suryo, D. (2001). Pelayaran Sungai Di Kalimantan Tenggara: Tinjauan Historis Tentang Transportasi Air Abad XIX. Yogyakarta: Universitas Gadjah Mada.
Suripin. (2011). Sistem Drainase Yang Berkelanjutan. Yogyakarta: Andi Offset.

Susilowati. (2007). Analisis Hidrograf Aliran Sungai Dengan Adanya Beberapa Bendung Kaitannya Dengan Konservasi Air. Tesis Magister, Program Studi Ilmu Lingkungan Program Pascasarjana Universitas Sebelas Maret, Surakarta.

Tella, Ramsis Yeferson. (2005). Analisis Penanggulangan Banjir Sungai Benanain Ditinjau dari Aspek Sosial Ekonomi dan Kehandalan Bangunan. Tesis, Program Magister Pengembangan Sumber Daya Air Institut Teknologi Bandung.

Utami, Tri. (2016). Desain Penampang Sungai Way Besai Melalui Peningkatan Kapasitas Sungai Menggunakan Software HEC-RAS. Skripsi, Fakultas Teknik Universitas Lampung. 